\title{
The Importance of Utilizing Gravity Tensor Invariant in Determining Hydrocarbon Locations
}

\section{Hidrokarbon Konumlarının Belirlenmesinde Gravite Tensör Değişmezinden Yararlanmanın Önemi}

\section{FIKRET DOĞRU1*ic}

${ }^{1}$ Ataturk University, Oltu Vocational College, Construction, 25400, Oltu, Erzurum, Turkey.

Geliş (received): 6 Ekim (October) 2021 Kabul (accepted): 06 Aralık (December) 2021

\begin{abstract}
The region, which covers the northeast of Syria and the northwest of Iraq in the south of the Bitlis-Zagros Suture Belt, which was formed as a result of the collision of the Arabian and Eurasian plates during the Middle Miocene and Early Late Miocene, has a very important position in the world in terms of hydrocarbons. Hydrocarbon exploration activities require enormous labour and cost. It is aimed to show that the locations of the known hydrocarbon fields in the region coincide with the maximum values of the gravity tensor invariant with this study. In this way, it is aimed to show that both the working area can be narrowed, and the cost can be reduced by applying this method beforehand in similar regions. For this purpose, World Gravity Map 2012 global model gravity data, which is one of the most up-to-date satellite-based gravity data used by many researchers recently, was used. First of all, the spherical free air and complete spherical Bouguer gravity data were analyzed and then the potential was obtained by taking the vertical integration of the complete spherical Bouguer data. Tensors were calculated by using this potential data and gravity tensor invariant was calculated from tensors. When the gravity tensor invariant map is examined, it is observed that the areas with the maximum positive values observed, and the locations of the known oil wells are mostly compatible throughout the area. As a result, it would be very beneficial to apply this method for the region first for such high-cost studies.
\end{abstract}

Keywords: Bouguer, gravity, hydrocarbon, Iraq, Syria, tensor.

\section{ÖZ}

Orta Miyosen ve Erken Geç Miyosen sürecinde Arabistan ile Avrasya levhalarının çarpışması sonucu oluşan Bitlis-Zagros Kenet Kuşağı'nın güneyindeki Suriye'nin Kuzeydoğusu ile Irak'ın kuzeybatısını içine alan bu bölge hidrokarbon açısından dünyada çok önemli bir konuma sahiptir. Hidrokarbon arama faaliyetleri çok büyük emek ve maliyet gerektirmektedir. Bu çalışma ile bölgedeki bilinen hidrokarbon alanlarının yerlerinin gravite tensör değişmezinin maksimum değerleri ile çakıştığını göstermek amaçlanmıştır. $\mathrm{Bu}$ sayede benzer bölgelerde öncesinde bu yöntem uygulanarak hem çalışma alanının daraltılabileceği hem de maliyetin düşürülebileceğini göstermek hedeflenmiştir. Bu amaçla son zamanlarda çok fazla araştırmacı tarafından kullanılmakta olan uydu tabanlı gravite verilerinden en güncel olanlarından biri olan World Gravity Map 2012 global modeli gravite verileri kullanılmıştır. Öncelikle küresel serbest hava, tam küresel Bouguer gravite verileri analiz edilmiş ve sonrasında tam küresel Bouguer verisinin düşey integrali alınarak potansiyel elde edilmiştir. Bu potansiyel verisi kullanılarak tensörler ve tensörlerden de gravite tensör değişmezi hesaplanmıştır. Gravite tensör değişmez haritası incelendiğinde gözlenen maksimum pozitif değerlerin olduğu alanlar ile bilinen petrol kuyularının yerlerinin alan genelinde çoğunlukla uyumlu olduğu gözlenmektedir. Sonuç olarak böylesi büyük maliyetli çalışmalar için öncelikle bu yöntemin bölge için uygulanması çok faydalı olacaktır.

Anahtar Kelimeler: Bouguer, gravite, hidrokarbon, Irak, Suriye, tensör. 


\section{INTRODUCTION}

Owning energy resources, being able to produce energy and keeping the transportation routes under control that will bring the energy to the market are among the issues that states focus on in their foreign policy. The resources that have the largest share in primary energy production are oil, coal and natural gas, respectively. The member states of the Organization of Petroleum Exporting Countries (OPEC) have $71.6 \%$ of the world's oil reserves. Looking at the regional distribution of oil reserves today, it is seen that the Middle East region has almost half of the world's oil reserves with $48.5 \%$ (Aksoy, 2016). In this study, the area includes northern Iraq in which contain about 45 billion barrels of Iraq's 115 billion barrels of oil reserves that makes Iraq the sixth-largest oil reserve in the World (AlZubaidi and Al-Zebari, 1998; Jassim and Al-Gailani, 2006; Abdula, 2010).

Oil and natural gas explorations should be completed in the shortest time with the lowest cost due to the high cost and difficulties in the advanced technology used in drilling. In addition, drilling costs increase apparently because most of the new explorations are done offshore or inaccessible depths (Gullu et al., 2021). For these reasons, it is very important to perform pre-study and planning effectively in hydrocarbon research. The size of the planned research area also increases the cost and exploration time. In this study, it is suggested that this method, which gives fast and costless results for the large area planned in future studies, is applied and other methods should be planned according to these results. Thus, since the area will be narrowed, both the search cost and the working time will be saved. A similar study was carried out by Dogru (2022) in the east of the Black Sea, and it was seen that the maximum values obtained were compatible with the known well locations.

The satellite-based gravity models have been used by many researchers lately for different purposes. World
Gravity Map 2012 (WGM2012) gravity model was used in this study to obtain gravity tensor invariants from gravity tensors. Gravity tensor invariants were used for satellite gravity gradiometry by the study of Baur et al., (2008). Oruc (2010) used gravity tensor invariants to estimate the depth of causative sources. Bouman et al., (2011) used the gravity tensor invariants in the gravity data combination study for geophysical exploration research. Gravity gradients and invariants were used for geophysical modelling by Ebbing et al., (2015). Satellite-based gravity disturbance data was used to obtain invariants in Western Anatolia by Dogru and Pamukcu (2019). Curvature gravity gradient tensor was used for the structural interpretation of the Erzurum Basin and the enhancement of linear features from gravity anomalies by Oruc (2011) and Oruc et al., (2013), respectively.

Within the scope of the study, gravity tensor invariant was calculated from the gravity tensors which were obtained from satellite-based gravity model (WGM2012). Afterwards, the known well locations were compared with the maxima values of gravity tensor invariants and most of the area gave compatible results.

\section{TECTONIC SETTING OF THE STUDY AREA}

Zagros Mountain and Bitlis-Zagros Suture Zone (BZSZ) was created by the collision of the Arabian Plate crust under the Eurasian Plate and the junction continues at present (Beydoun et al., 1992). The study area, which is bordered by BZSZ in the north and the Dead Sea Fault in the west, includes several thrusts/blind thrusts in northeast Syria and northwest Iraq (Seyitoglu et al., 2017). The basement rocks in northern Iraq are broken into several blocks which the Kirkuk and northern Mosul are the main ones (Ameen, 1992). A general tectonic map of the study area is given in Figure 1. 


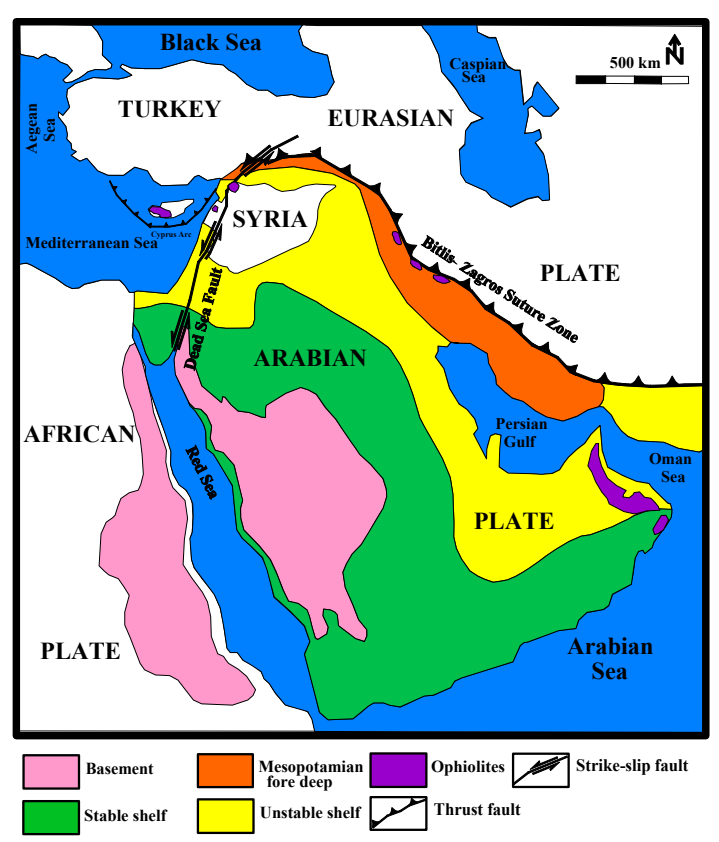

Figure 1. The general tectonic map of the study area. (The map modified from Barrier et al., 2014).

Şekil 1. Çalışma alanının genel tektonik haritası. (Barrier et al., 2014'den revise edildi).

\section{World Gravity Map (WGM2012) Gravity Model}

World Gravity Map (WGM2012), European Improved Gravity model of the Earth by New techniques (EIGEN6C-4) (Förste et al., 2014), Gravity field and steady-state Ocean Circulation Explorer (GOCE) and Earth Gravitational Model 2008 (EGM2008) (Pavlis et al., 2008) combined model (GECO) (Gilardoni et al., 2016), ITSG-Grace2018s (Mayer-Gürr et al., 2018), XGM2019e_2159 (Zingerle et al., 2020), SGG-UGM-2 (Liang et al., 2020) have been used by many researchers lately. WGM2012 gravity anomalies are derived from EGM2008 and DTU10 (Global Ocean Tide model of Technical University of Denmark) and include " $1 \times 1$ " resolution terrain corrections derived from ETOPO1 model (Bonvalot et al., 2012).

The topography of the study area reaches up to 1400 meters, but the values change between 200 to 600 meters in general (Figure 2). The gravity anomalies were calculated from the WGM2012 gravity model. The spherical free-air gravity anomaly values change between -60 to $90 \mathrm{mGal}$ depending on the topography (Figure 3 ). In the region where the maximum values of the topography are, spherical free air values reach up to $90 \mathrm{mGal}$. Complete spherical Bouguer gravity anomaly values change between 20 to $100 \mathrm{mGal}$ and the maximum values are concentrated in the middle of the region (Figure 4).

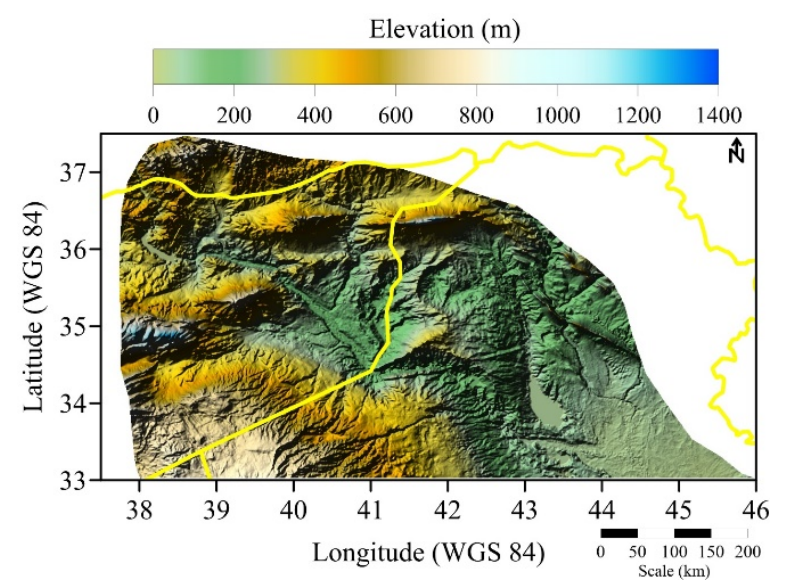

Figure 2. The topography of the study area (SRTM 3 arc sec data was downloaded from the USGS Earth Explorer website (https://earthexplorer.usgs.gov) (Yellow line indicates the country borders).

Şekil 2. Çalışma alanının topoğrafyası (SRTM 3 arc sec verileri USGS Earth Explorer web sitesinden (https://earthexplorer.usgs.gov) indirilmiştir (Sarı çizgi ülke sınırlarını göstermektedir).

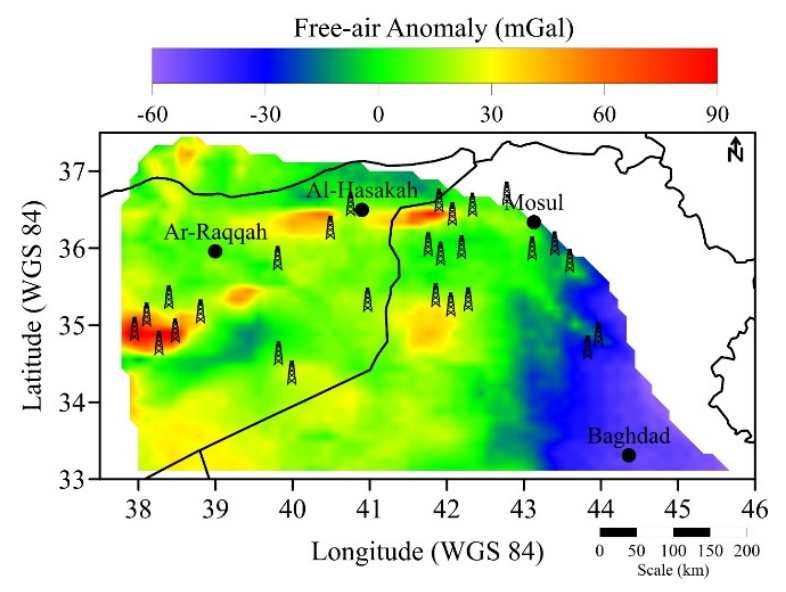

Figure 3. The Free-air gravity anomaly map of the study area with known hydrocarbon locations which were taken from Barrier et al., 2014 in Syria (Black line indicate the country borders).

Şekil 3. Barrier et al., 2014'den alınan Suriye'de bilinen hidrokarbon yerlerine sahip çalışma alanına ait serbest hava gravite anomalisi (Siyah çizgiler ülke sınırlarını göstermektedir). 


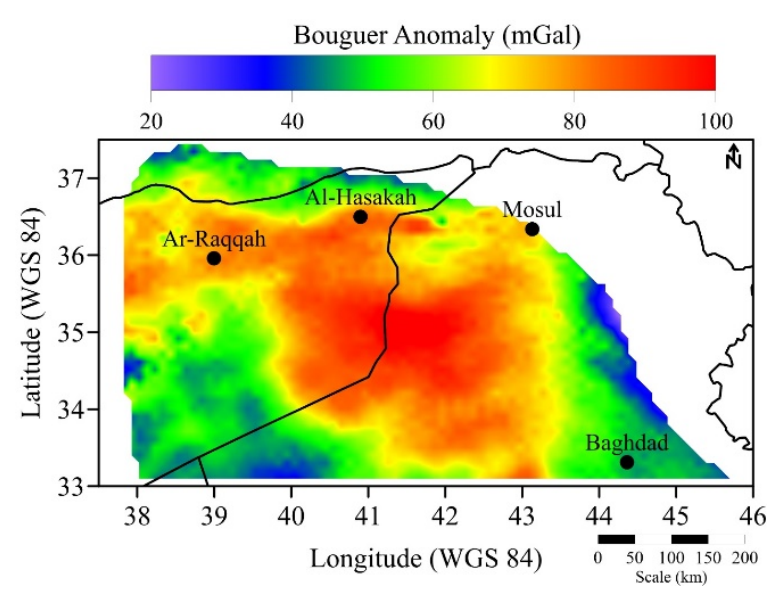

Figure 4. The Complete Bouguer gravity anomaly of the study area (Black line indicate the country borders).

Şekil 4. Çalışma alanına ait Tam Bouguer gravite anomalisi (Siyah çizgiler ülke sınırlarını göstermektedir).

\section{Gravity Tensor and Invariants}

Gravity tensor $\mathbf{T}$ is a tensor of the second derivatives of the gravity potential P (Klokočník et al., 2014). In this study, $\mathbf{P}$ was calculated by taking vertical integration of Bouguer gravity data. The formulas used to calculate the gravity potential $\mathrm{P}$ are given in detail by Barthelmes (2009). Then the second derivates of gravity potential presented tensor components:

$T=\left[\begin{array}{ccc}T_{x x} & T_{x y} & T_{x z} \\ T_{y x} & T_{y y} & T_{y z} \\ T_{z x} & T_{z y} & T_{z z}\end{array}\right]=\left[\begin{array}{ccc}\frac{\partial^{2} P}{\partial x^{2}} & \frac{\partial^{2} P}{\partial x \partial y} & \frac{\partial^{2} P}{\partial x \partial z} \\ \frac{\partial^{2} P}{\partial y \partial x} & \frac{\partial^{2} P}{\partial y^{2}} & \frac{\partial^{2} P}{\partial y \partial z} \\ \frac{\partial^{2} P}{\partial z \partial x} & \frac{\partial^{2} P}{\partial z \partial y} & \frac{\partial^{2} P}{\partial z^{2}}\end{array}\right]$

In addition, invariants were calculated from gravity tensors and only invariant $2\left(\boldsymbol{I}_{2}\right)$ was utilized to determine the location of hydrocarbon areas. In general, the formula of three invariants is given following:

$$
\begin{aligned}
& I_{0}=T_{x x}+T_{y y}+T_{z z} \\
& I_{1}=T_{x x} T_{y y}+T_{y y} T_{z z}+T_{z z} T_{x x}-T_{x y}{ }^{2}-T_{y z}{ }^{2}-T_{x z}{ }^{2} \\
& I_{2}=T_{x x}\left(T_{y y} T_{z z}-T_{y z}{ }^{2}\right)+T_{x y}\left(T_{y z} T_{x z}-T_{x y} T_{z z}\right)+ \\
& T_{x z}\left(T_{x y} T_{y z}-T_{x z} T_{y y}\right)
\end{aligned}
$$

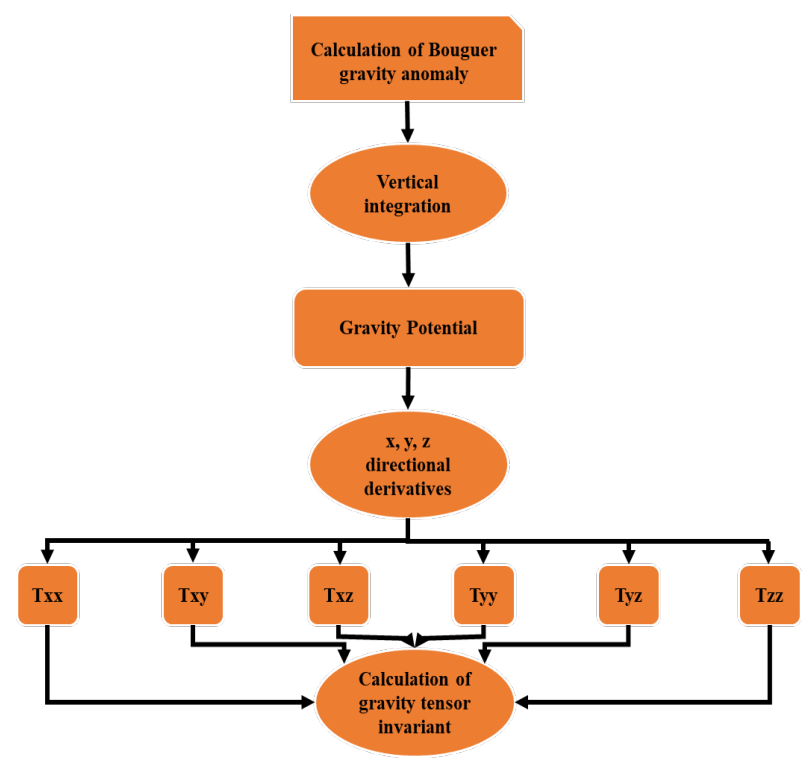

Figure 5. The flowchart of the gravity invariant calculation.

Şekil 5. Gravite değişmez hesabının akış şeması.

After vertical integration of complete spherical Bouguer gravity anomaly, the gravity potential (P) map was obtained, and tensors were calculated by using this potential data. The flowchart of the gravity invariant calculation is given in Figure 5. Gravity potential values change between 6000 to $21000 \mathrm{~km}^{2} / \mathrm{s}^{2}$ (Figure 6). The gravity tensors were calculated from the second derivatives of potential (Figure 7). 


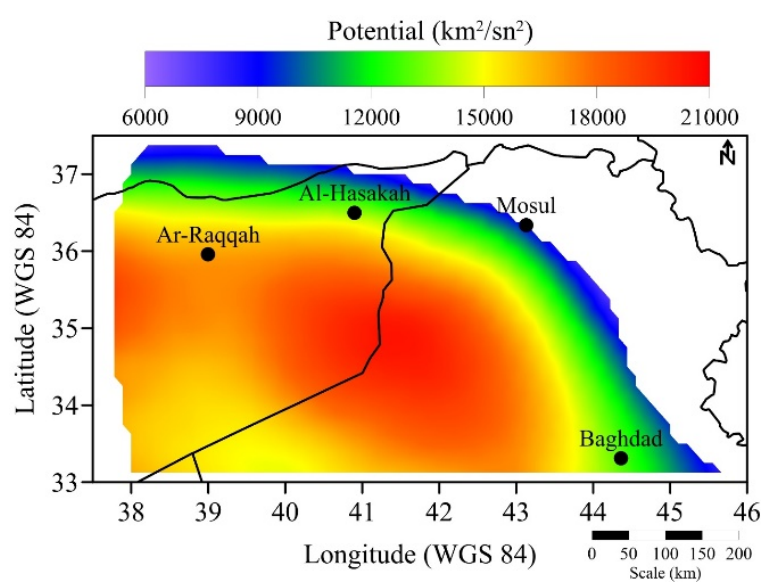

Figure 6. The gravity potential map (P) was obtained from the Complete Bouguer gravity anomaly (Black line indicate the country borders).

Şekil 6. Tam Bouguer gravite anomalisinden hesaplanan gravite potansiyel haritası $(P)$ (Siyah çizgiler ülke sınırlarını göstermektedir).

$\mathbf{T}_{\mathbf{x x}}$ and $\mathbf{T}_{\mathbf{y y}}$ tensor components give information about the horizontal and vertical structures, respectively. $\mathbf{T}_{\mathbf{z z}}$ tensor is the best fit for the subsurface structure detection (Murphy and Dickinson, 2009). Then gravity tensor invariant was calculated from gravity tensors and the gravity tensor invariant map was given with the known oil well locations (Figure 8).

\section{DISCUSSION}

Within the scope of the study, first of all, spherical free-air gravity anomaly and complete spherical Bouguer gravity anomaly were obtained from the satellite-based gravity model of WGM2012. The spherical free-air gravity anomaly values were compatible with the topography and maximum values were shown in the middle of the study area as the result of the complete spherical Bouguer anomaly values. Then, the gravity potential of the complete spherical Bouguer gravity anomaly was calculated using vertical integration in order to gather gravity tensors by taking second-order derivatives. Tensors gave mostly information about the discontinuities all over the area or the location of subsurface structures. The synthetic trials about tensors were made by Dogru and Pamukcu (2019) succesfully. In addition, gravity tensor invariant was calculated from gravity tensor components. It is shown that there is consistency between the maximum values in the gravity tensor invariant map with known well locations as in the study of Dogru (2022).

The gravity tensor invariant map shows its sensitivity to the density variations. The hydrocarbon leaves the source rock and settles into different rocks by following a migration path. It contains a density difference compared to the environment in the trap where it accumulates afterwards. Thus, it is thought that the maxima of gravity tensor invariant is sensitive to this density difference from the results of this study.

The easy application and cost-effectiveness of the method reveal the necessity of using it as a preliminary study in such studies. With this method, the working area will be reduced, thus saving both money and time. Since it is valuable to obtain these results with such an easy effort for such costly studies, it is recommended to use this method in hydrocarbon explorations.

\section{ACKNOWLEDGMENTS}

I would thank to the editor and anonymous reviewers for their valuable time and comments in the development of the publication. 

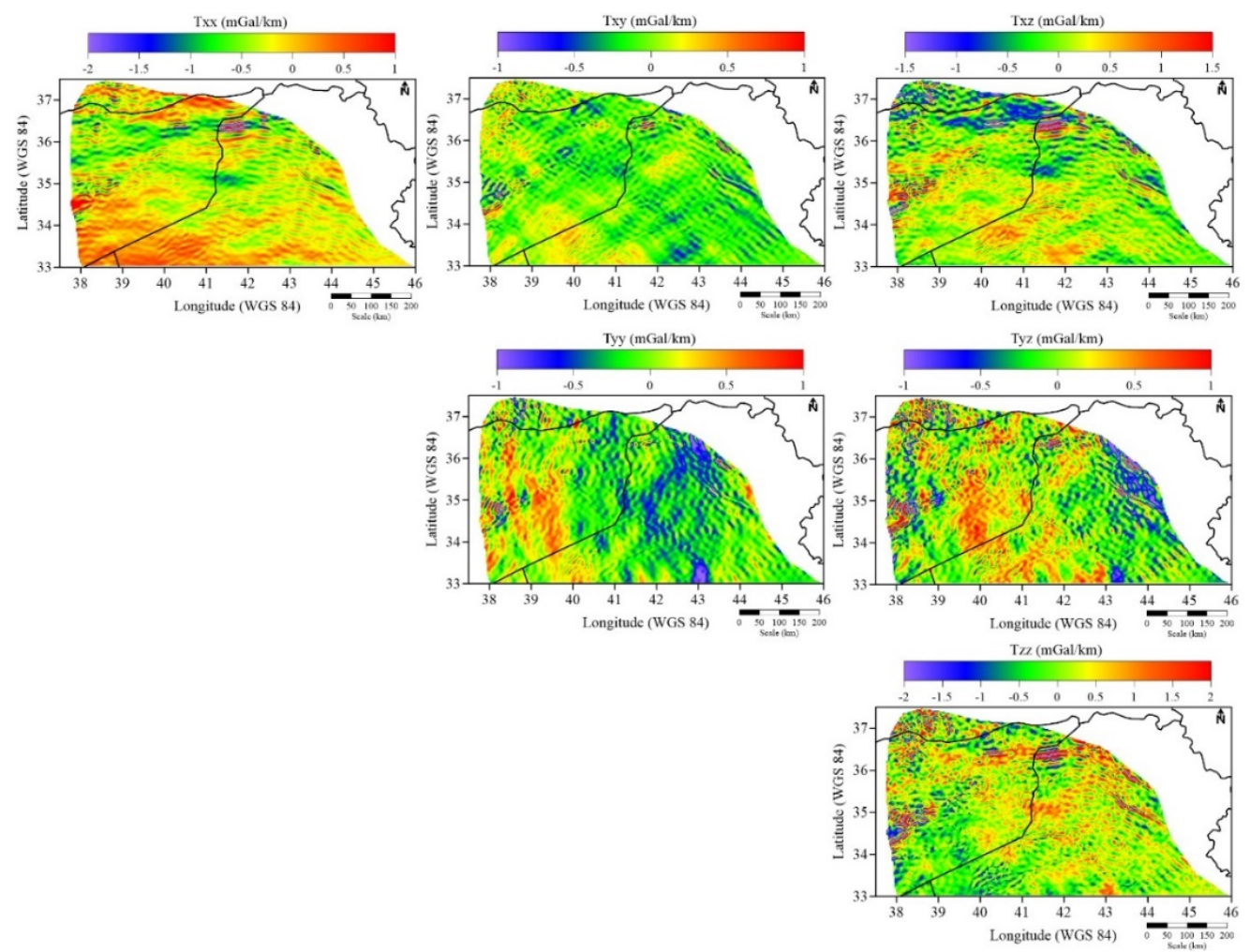

Figure 7. The tensor components: $T_{x x}, T_{x y}, T_{x z}, T_{y y}, T_{y z}$ and $T_{z z}$ (Black line indicate the country borders).

Şekil 7. Tensör bileşenleri: $T_{x x}, T_{x y}, T_{x z}, T_{y y}, T_{y z}$ ve $T_{z z}$ (Siyah çizgiler ülke sınırlarını göstermektedir).

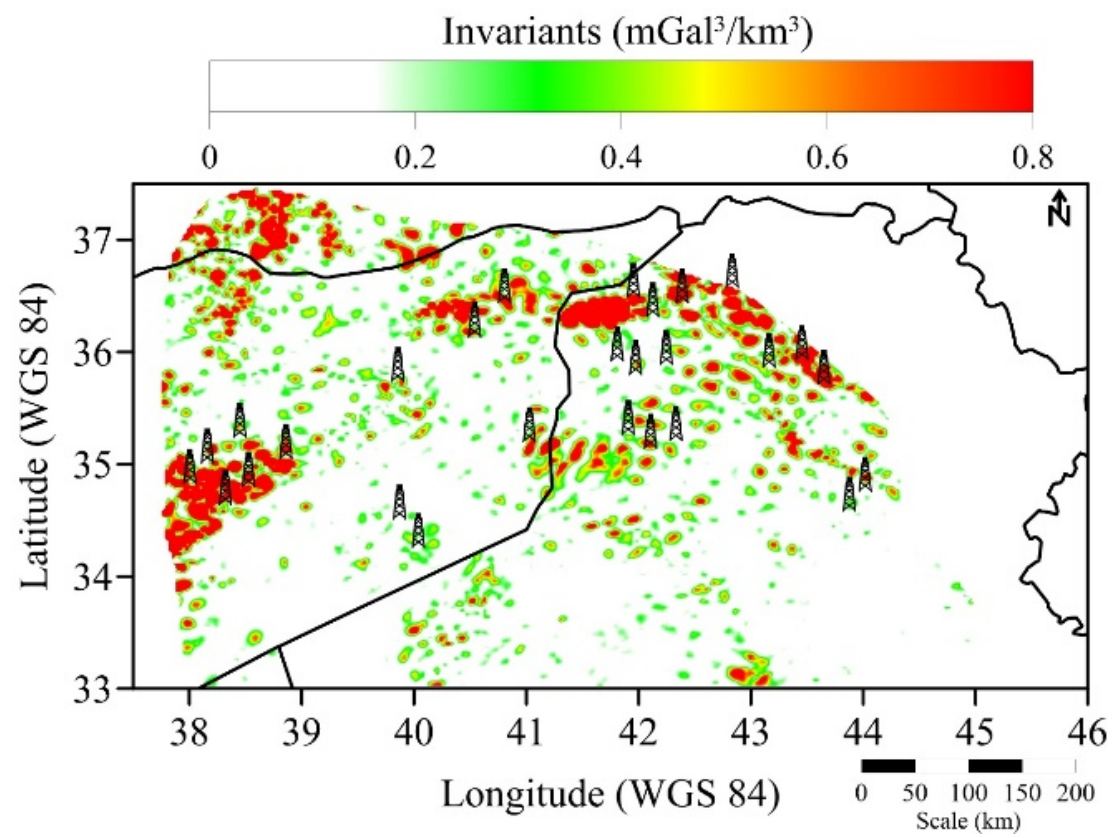

Figure 8. The $I_{2}$ map was calculated from tensors with known hydrocarbon locations which were taken from Barrier et al., (2014) in Syria (Black line indicate the country borders).

Şekil 8. Barrier et al., 2014'den alınan Suriye'de bilinen hidrokarbon yerlerine sahip çalışma alanına ait $I_{2}$ haritası (Siyah çizgiler ülke sınırlarını göstermektedir). 


\section{REFERENCES}

Abdula, R., 2010. Petroleum source rock analysis of the Jurassic Sargelu Formation. Northern Iraq: Master's thesis, Colorado School of Mines.

Aksoy, M., 2016. Dünyanın enerji görünümü. Insamer Araştırma 25, 32.

Al-Zubaidi, A.A., and Al-Zebari, A.Y., 1998. Prospects for production and marketing of Iraq's heavy oil. Ministry of Oil, State Oil Marketing, Baghdad, Iraq, 1998.221,10.

Barrier, E., Machhour, L., and Blaizot, M., 2014. Petroleum systems of Syria, in L. Marlow, C. Kendall and L. Yose, eds., Petroleum systems of the Tethyan region: AAPG Memoir 106, p. 335-378.

Barthelmes, F., 2009. Definition of functionals of the geopotential and their calculation from spherical harmonic models: theory and formulas used by the calculation service of the International Centre for Global Earth Models (ICGEM), http://icgem. gfzpotsdam.de.

Baur, O., Sneeuw, N., and Grafarend, E.W., 2008. Methodology and use of tensor invariants for satellite gravity gradiometry. Journal of Geodesy, 82(4-5), 279-293.

Bonvalot, S., Balmino, G., Briais, A., Kuhn, M., Peyrefitte, A., Vales, N., Biancale, R., Gabalda, G., Reinquin, F., and Sarrailh, M., 2012. World gravity map. Commission for the Geological Map of the World. Eds. BGICGMW-CNES-IRD, Paris.

Bouman, J., Ebbing, J., Fuchs, M., Schmidt, M., Bosch, W., Schwatke, C., and Schavemaker, Y., 2011. Heterogeneous gravity data combination for Earth interior and geophysical exploration research. In Proceedings GOCE User Workshop 2011.

Dogru, F., and Pamukcu, O., 2019. Analysis of gravity disturbance for boundary structures in the Aegean Sea and Western Anatolia. Geofizika, 36(1), 53-76.

Dogru, F., 2022. Exploring of Invariants and Euler Deconvolution of Eastern Part of Black Sea. [in press].
Ebbing, J., Bouman, J., and Skaar, J.A., 2015. The use of gravity gradients and invariants for geophysical modelling-Example from airborne and satellite data. In International Workshop and Gravity, Electrical \& Magnetic Methods and their Applications, Chenghu, China, 19-22 April 2015 (pp. 177-180). Society of Exploration Geophysicists and Chinese Geophysical Society.

Förste, C., Bruinsma, S. L., Abrikosov, O., Lemoine, J. M., Schaller, T., Götze, H. J., and Biancale, R., 2014. EIGEN-6C4 The latest combined global gravity field model including GOCE data up to degree and order 2190 of GFZ Potsdam and GRGS Toulouse. GFZ Data Services.

Gilardoni, M., Reguzzoni, M., and Sampietro, D., 2016. GECO: a global gravity model by locally combining GOCE data and EGM2008. Stud Geophys Geod, 60:228-247.

Gullu, A., Yaşar, E., and Özdemir, A., 2021. Türkiye'deki Petrol ve Doğalgaz Sondaj Kuyularının Optimizasyonu. European Journal of Science and Technology, 27, 398-406.

Jassim, S.Z., and Al-Gailani, M., 2006. Hydrocarbons, chapter 18, in Jassim, S.Z., and J.C. Goff, eds., Geology of Iraq, first edition: Brno, Czech Republic, Prague and Moravian Museum, 232-250.

Liang, W., Li, J., Xu, X., Zhang, S., and Zhao, Y., 2020. A High-Resolution Earth's Gravity Field Model SGG-UGM-2 from GOCE, GRACE, Satellite Altimetry, and EGM2008. Engineering, 6(8), 860-878.

Mayer-Gürr, T., Behzadpur, S., Ellmer, M., Kvas, A., Klinger, B., Strasser, S., and Zehentner, N., 2018. ITSG-Grace2018 - Monthly, Daily and Static Gravity Field Solutions from GRACE. GFZ Data Services.

Murphy, C.A., and Dickinson, J.L., 2009. Exploring exploration play models with FTG gravity data, in: $11^{\text {th }}$ SAGA Biennial Technical Meeting and Exhibition, Swaziland, 16-18 September 2009, 89-91.

Oruc, B., 2010. Depth estimation of simple causative sources from gravity gradient tensor invariants and vertical component. Pure and applied geophysics, 167(10), 12. 
Oruc, B., 2011. Enhancement of linear features from gravity anomalies by using curvature gradient tensor matrix. In 6th Congress of the Balkan Geophysical Society (pp. cp-262). European Association of Geoscientists \& Engineers.

Oruc, B., Sertcelik, İ., Kafadar, Ö., and Selim, H.H., 2013. Structural interpretation of the Erzurum Basin, eastern Turkey, using curvature gravity gradient tensor and gravity inversion of basement relief. Journal of Applied Geophysics, 88, 105-113.59-1272.

Pavlis, N.K., Holmes, S.A., Kenyon, S.C., and Factor, J.K., 2008. The EGM2008 global gravitational model. In AGU Fall Meeting Abstracts, G22A-01.

Seyitoglu, G., Esat, K., and Kaypak, B., 2017. The neotectonics of southeast Turkey, northern Syria, and Iraq: the internal structure of the Southeast Anatolian Wedge and its relationship with recent earthquakes. Turkish Journal of Earth Sciences, 26(2), 105-126.

Zingerle, P., Pail, R., Gruber, T., and Oikonomidou, X., 2020. The combined global gravity field model XGM2019e. Journal of Geodesy, 94(7), 1-12. 